\title{
Proton pump inhibitor-refractory gastroesophageal reflux disease: challenges and solutions
}

This article was published in the following Dove Press journal:

Clinical and Experimental Gastroenterology

Joseph Mermelstein'

Alanna Chait Mermelstein ${ }^{2}$

Maxwell M Chait ${ }^{3}$

'Gasteroenterology and Nutrition Service, Department of Medicine, Memorial Sloan Kettering Cancer Center, New York, NY, USA;

${ }^{2}$ Department of Psychiatry and Behavioral Sciences, Memorial Sloan Kettering Cancer Center, New York, NY, USA; ${ }^{3}$ Department of Medicine, Columbia University College of Physicians and Surgeons, New York, NY, USA
Correspondence: Maxwell M Chait Columbia Doctors Medical Group, 180 East Hartsdale Avenue, Hartsdale, NY 10530, USA

$\mathrm{Tel}+19147252010$

Fax +19147256488

Email maxwellchait@gmail.com

\begin{abstract}
A significant percentage of patients with gastroesophageal reflux disease (GERD) will not respond to proton pump inhibitor (PPI) therapy. The causes of PPI-refractory GERD are numerous and diverse, and include adherence, persistent acid, functional disorders, nonacid reflux, and PPI bioavailability. The evaluation should start with a symptom assessment and may progress to imaging, endoscopy, and monitoring of esophageal $\mathrm{pH}$, impedance, and bilirubin. There are a variety of pharmacologic and procedural interventions that should be selected based on the underlying mechanism of PPI failure. Pharmacologic treatments can include antacids, prokinetics, alginates, bile acid binders, reflux inhibitors, and antidepressants. Procedural options include laparoscopic fundoplication and LINX as well as endoscopic procedures, such as transoral incisionless fundoplication and Stretta. Several alternative and complementary treatments of possible benefit also exist. Keywords: PPI failure, resistant GERD, acid-related diseases, gastroesophageal reflux disease, acid reflux, proton pump inhibitors
\end{abstract}

\section{Introduction}

Gastroesophageal reflux disease (GERD), the most common upper gastrointestinal (GI) disorder in the US, ${ }^{1}$ is defined as symptoms or lesions that result from the retrograde flow of gastric contents into the esophagus. ${ }^{2}$ Proton pump inhibitors (PPIs), after acid activation to sulfonamides, covalently bind to cysteine residues on the luminal surface of $\mathrm{H}^{+} / \mathrm{K}^{+}$ATPase proton pumps in the parietal cells, blocking ion transport and acid secretion. Chemically, all PPIs consist of a benzimidazole ring and a pyridine ring but vary in side ring substitution. ${ }^{1}$ Although PPIs are currently the most effective treatment for GERD and its complications, ${ }^{3}$ up to $40 \%$ of patients with nonerosive reflux disease (NERD) remain symptomatic on standard therapy, and approximately $10-15 \%$ of patients with erosive esophagitis (EE) do not achieve full remission after 8 weeks of treatment., ${ }^{4,5}$

Patients with continued symptoms despite PPI treatment are considered to have refractory GERD, which is generally defined as the persistence of typical symptoms that do not respond to stable, twice-daily PPI dosing during at least 12 weeks of treatment. ${ }^{6-8}$ Up to $30 \%$ of GERD patients experience refractory GERD. ${ }^{2}$

\section{Causes of refractory GERD}

There are many potential causes of refractory GERD that vary in incidence, clinical importance, and symptom severity and frequency. Poor compliance and adherence should first be assessed before further evaluation is pursued. The most common 
mechanisms for refractory GERD include functional bowel disorders, weakly acidic reflux, and residual acid. Factors related to metabolism and bioavailability play a limited role in PPI failure. GERD-like symptoms may also be due to a variety of other disorders, such as eosinophilic esophagitis (EoE), pill-induced esophagitis, infectious esophagitis, and achalasia, which should be considered in the differential diagnosis of patients with unremitting symptoms (Table 1).

\section{Factors related to medication administration \\ PPI adherence and compliance}

An important initial consideration for all patients not fully responding to PPI therapy is to evaluate medication adherence, as regular medication administration is crucial for maximal efficacy. Several studies indicate poor medication adherence among PPI users, with two reports finding that only $53.8 \%$ and $67.7 \%$ of patients filled their monthly PPI prescription more than $80 \%$ of the time. ${ }^{9,10}$ Moreover, many patients discontinue PPIs when their symptoms resolve, as demonstrated by a large population-based survey in which only $55 \%$ of patients took a PPI once daily for 4 weeks as prescribed, with $37 \%$ taking it for 12 or fewer days out of the month. ${ }^{11,12}$

Medication compliance is also important to investigate, as several studies show that patients do not use PPIs at the appropriate time. One study of 100 patients with persistent GERD symptoms found that only $8 \%$ of patients reported dosing at the optimal 30-60 minutes prior to meal. ${ }^{13} \mathrm{Com}-$ mon reasons for nonadherence and noncompliance include absence of symptoms, personal preference, side effects, and lack of knowledge or misinformation about medication, ${ }^{14}$ as demonstrated by one national survey that $36 \%$ of physicians give their patients no directions or incorrect directions

Table I Causes of refractory GERD

- PPI adherence and compliance

- Functional esophageal disorders

- Functional heart burn, esophageal hypersensitivity, IBS

- Weakly acidic or nonacid reflux

- Weakly acid reflux, duodenogastroesophageal reflux

- Residual acid

- NAB, acid pocket

- Delayed gastric emptying

- Rapid PPI metabolism

- Eosinophilic esophagitis

- Causes unrelated to GERD

Abbreviations: GERD, gastroesophageal reflux disease; PPI, proton pump inhibitor; IBS, irritable bowel syndrome; NAB, nocturnal acid breakthrough. regarding mealtime dosing of PPIs, $26 \%$ give no instructions or say that timing is unimportant, and $10 \%$ incorrectly advise their patients to take them with or after food. ${ }^{15}$

\section{Choice of agent}

Limited data directly compares the efficacy of different PPIs. Although some studies suggest that certain PPIs may be more effective for GERD, this is not supported by a meta-analysis of pooled data. ${ }^{16}$ Therefore, choice of agent is an unlikely cause of refractory GERD.

\section{Factors associated with functional esophageal disorders}

Functional GI disorders have traditionally been defined as symptomatic disorders without known structural, metabolic, or infectious cause. ${ }^{17}$ Functional disorders likely result from a diverse group of underlying mechanisms, which may include increased mucosal sensitivity to mechanical and chemical stimulation or worsened central perception of pain. ${ }^{18}$

\section{Functional heartburn}

Rome IV defines functional heartburn as 3 months of burning retrosternal pain without evidence of continued reflux or underlying motility disorder that is not relieved by optimal antisecretory therapy. ${ }^{18}$ As many as $58 \%$ of patients with refractory GERD fall into this category. ${ }^{19,20}$

\section{Esophageal hypersensitivity}

Esophageal hypersensitivity, which is defined as the heightened perception of various stimuli, including acid, temperature, mechanical distention, and electrical stimulation, ${ }^{21}$ may contribute to persistent GERD symptoms despite PPI therapy. The mechanism of esophageal hypersensitivity is unclear but likely involves both peripheral and central sensitization via dilated intracellular spaces (DISs) and exposure of subepithelial nerves to acid. ${ }^{22-24}$ Esophageal hypersensitivity may also be influenced by stress, which can alter brain processing of sensation, autonomic nervous activity, cortisol release, and pathways involved in the spinal transmission of nociceptive signals. $^{22}$

Although the role of esophageal hypersensitivity in PPI failure has not been well studied, most treatment-refractory patients demonstrate a lower threshold for pain perception with esophageal balloon distention or electrical stimulation. ${ }^{25}$ Studies of patients with GERD who have been exposed to anxiety induction or acute auditory stress show increased perceptual response to acid exposure and exacerbation of 
symptoms. ${ }^{26,27}$ Further supporting the contribution of esophageal hypersensitivity to refractory GERD, DIS has been shown to resolve in patients who respond to PPI therapy ${ }^{28,29}$ but persist in those who remain symptomatic. ${ }^{30,31}$

\section{Factors affecting functional esophageal disorders Psychological comorbidity}

Data on the contribution of psychological comorbidity to refractory GERD are mixed. Several studies have shown that patients with GERD, particularly those with NERD, have a high prevalence of psychiatric disease and psychosocial stressors. ${ }^{32-37}$ In a recent analysis of PPI therapy in patients with psychological distress, high baseline levels of anxiety and depression, and decreased general well-being, predicted lower treatment response..$^{38}$ Another study similarly found that comorbid psychological distress was independently associated with more severe baseline GERD symptoms, greater residual symptoms, and worse disease-specific quality of life both before and after PPI therapy. ${ }^{39}$ Sleep dysfunction and a history of either psychotherapy or psychiatric medication have also been significantly associated with poor PPI response. ${ }^{40}$

In contrast to these findings, however, a recent prospective study of GERD patients receiving once- or twice-daily PPI therapy found that poor treatment response was not associated with anxiety or depression. ${ }^{41}$ A study of GERD patients in a primary care setting similarly revealed that the relative risk of anxiety or depression in PPI failure was minimal, with an odds ratio of $1.15 .^{42}$

The reported relationship between PPI failure and psychological distress is multifactorial. Psychiatric disease may compromise esophageal motor function by affecting the enteric nervous system. ${ }^{32,43,44}$ Some studies suggest that reflux symptoms may be affected by substance use ${ }^{45}$ and psychiatric medications, such as benzodiazepines, which can decrease lower esophageal sphincter (LES) pressure, ${ }^{46}$ and tricyclic antidepressants (TCAs), which block cholinergic receptors and may compromise acid clearance ${ }^{47}$ Sleep disturbance has also been associated with greater severity of reflux symptoms and poorer response to treatment. ${ }^{22}$

Psychological comorbidity may also affect perception of treatment success. In the setting of acute stress, patients report increased severity and frequency of GERD symptoms regardless of alteration in esophageal acid exposure. In a study of laparoscopic antireflux surgery for treatmentrefractory GERD, patients with coexisting major depressive disorder were more likely to report residual symptoms despite improvements on objective assessment scores. ${ }^{48}$
A prospective controlled trial of patients undergoing a laparoscopic Nissen fundoplication similarly found that patients with refractory GERD symptoms had a significantly higher level of somatization. ${ }^{49}$

\section{Irritable bowel syndrome}

The overlap between GERD and irritable bowel syndrome (IBS) has been recognized for more than 20 years, with up to $71 \%$ of GERD patients reporting IBS symptoms. ${ }^{50,51}$ The association between IBS and GERD is thought to result from either common underlying mechanisms or symptoms. ${ }^{52}$

Data is limited, but studies have shown that concomitant IBS predicts poorer treatment response in patients with GERD. In one prospective, open-label study, patients with GERD and IBS-like symptoms showed reduced response rates to pantoprazole when compared to patients without IBSlike symptoms..$^{52}$ Another study similarly found that comorbid IBS was associated with increased GERD symptoms and lower quality of life both before and after PPI treatment, although this may reflect more severe baseline symptoms that are less responsive to treatment. ${ }^{39}$

\section{Weakly acidic or nonacid reflux Weakly acidic reflux}

Weakly acidic reflux is defined as a reflux event in which the esophageal $\mathrm{pH}$ falls by at least one unit but not below four. ${ }^{53}$ The exact mechanism through which weakly acid reflux produces symptoms remains unclear, but several theories have been proposed based on the volume or content of refluxate. A large volume of weakly acidic refluxate may cause mechanical dilation of the esophagus and induce reflux symptoms, as demonstrated by studies in which direct mechanical balloon dilation of the esophagus causes heartburn sensation. ${ }^{54,55}$ GERD symptoms can also result from bile acids, which may be contained in weakly acidic reflux. ${ }^{56}$ The proteolytic effect of pepsin, which can be introduced into the esophagus during a weakly acidic reflux event, may also contribute to refractory symptoms. While pepsin is maximally active at a pH of 1.9-3.6, it maintains some activity up to a $\mathrm{pH}$ of 6 . Additionally, pepsin maintains its structure up to a $\mathrm{pH}$ of at least 7.5 and can be reactivated by a subsequent acid reflux event or acidic meal. ${ }^{57}$ Esophageal healing may also be compromised because the restoration and regeneration of the mucosa are inhibited at $\mathrm{pH}$ $<6.5 .{ }^{57}$ Finally, previous exposure of the esophagus to acid can lead to subsequent hyperalgesia to both mechanical and chemical stimulation..$^{58-60}$ Additionally, patients with PPI-refractory GERD have been found to have slower esophageal clearance, ${ }^{61}$ which may exacerbate all the above mechanisms. 
The clinical significance of weakly acidic reflux in refractory GERD remains unclear. Although multiple studies show that only a minority of weakly acidic reflux events occur at the same time as refractory symptoms, a wide range (16.7-40\%) is reported. ${ }^{19,62-65}$

\section{Duodenogastroesophageal reflux (DGER)}

DGER refers to reflux of duodenal contents, including bile, through the stomach and into the esophagus. ${ }^{66}$ Esophageal bilirubin exposure can occur with or without weakly acidic reflux ${ }^{67}$ and lead to decreased esophageal mucosal integrity ${ }^{56}$ through epithelial cell apoptosis, DIS, and increased mucosal permeability. ${ }^{68,69}$ In one study of refractory GERD, DGER was found in $88 \%$ of PPI nonresponders and only $27 \%$ of responders. ${ }^{7}$ Another study similarly found that $64 \%$ of patients with GERD who did not respond to standard-dose PPI therapy had pathologic DGER. ${ }^{70}$

\section{Delayed gastric emptying}

In refractory GERD, the role of delayed gastric emptying, which should theoretically lead to larger or more frequent reflux events, remains unclear. One study of 66 patients with refractory GERD who underwent gastric emptying studies found no statistical difference between patients with gastroparesis and controls with respect to total number or duration of acid and nonacid reflux events. ${ }^{71}$ However, a smaller study found that after 8 weeks of PPI treatment, patients with persistent symptoms and EE had more abnormal gastric emptying as compared to patients with persistent $E E$ but no symptoms. ${ }^{72}$ A possible association between gastric emptying and refractory GERD was also demonstrated in a small study in which $88 \%$ of patients who experienced improvement in gastroparesis symptoms also reported reduced GERD symptoms. ${ }^{73}$

\section{Residual acid}

\section{Acid pocket}

Postprandially, there can exist an area of highly acidic gastric juice at the esophagogastric junction, termed an acid pocket, which contains newly secreted acid that does not mix with food and so remains unbuffered. This pocket may migrate into the esophagus and cause postprandial reflux symptoms. ${ }^{74}$ While PPI use may alter the location or reduce the size of the pocket, ${ }^{75}$ one of the only studies investigating this mechanism found no difference in location or $\mathrm{pH}$ of the acid pocket between PPI responders and partial responders. ${ }^{21}$

\section{Nocturnal acid breakthrough (NAB)}

$\mathrm{NAB}$ is defined as a gastric $\mathrm{pH}<4$ for at least 1 hour during the night in patients on PPI therapy. ${ }^{5}$ While NAB is very common, occurring in as many as $75 \%$ of patients on twice-daily PPI therapy, ${ }^{76}$ it likely does not play a role in the pathogenesis of resistant GERD. In one study of refractory GERD, 37 of 52 patients were found to have NAB, but only 17 had concurrent GERD symptoms. Additionally, there were a similar number of symptoms in patients with and without NAB. ${ }^{77}$ Another study found that adding ranitidine to twice-daily omeprazole did not improve nocturnal heartburn symptoms or sleep quality despite reductions in NAB. ${ }^{78}$

\section{Metabolism and bioavailability}

\section{Rapid PPI metabolism}

PPIs are metabolized in the liver by cytochrome P450 2C19 (CYP2C19) and to a much lesser extent by cytochrome $\mathrm{P} 450$ $3 \mathrm{~A} 4 .{ }^{79} \mathrm{As}$ a result of genetic polymorphisms, CYP2C19 exists as three possible genotype groups with varying metabolic activity: homozygous extensive metabolizers (carrying two mutated alleles), heterozygous extensive metabolizers (carrying one mutant and one wild-type allele), and poor metabolizers (carrying two wild-type alleles). ${ }^{79}$ There is a significant ethnic variation in the distribution of these alleles, as up to $70 \%$ of Caucasians, compared to $30-40 \%$ of Asians, are extensive metabolizers. ${ }^{80}$

Extensive metabolizers are expected to show decreased acid suppression in response to PPI therapy because more rapid elimination leads to decreased mean residence time and area under the curve. The area under the curve for poor metabolizers is reportedly 5-12 times higher than in extensive metabolizers. ${ }^{81}$ A recent meta-analysis found that PPI response rate in GERD among rapid metabolizers, intermediate metabolizers, and poor metabolizers was $52.2 \%, 56.7 \%$, and $61.3 \%$, respectively. ${ }^{82}$

The impact of CYP2C19 activity on refractory GERD symptoms remains unclear, as nearly all studies use standardrather than double-dose PPI therapy ${ }^{82}$ There is only one study examining the difference in response rate between extensive and poor metabolizers on both standard and twice-daily pantoprazole. After 8 weeks of therapy, sustained symptom response (SSR) did not differ between poor metabolizers who were receiving either dose of pantoprazole. Heterozygous extensive metabolizers showed an SSR of $94.9 \%$ on twice-daily dosing but only $73.7 \%$ on standard dosing. Similarly, homozygous extensive metabolizers showed an SSR of $82.1 \%$ on twice-daily dosing as compared to $68.4 \%$ 
on standard dosing. ${ }^{83}$ The discrepancy between response rate of double- and standard-dose PPI among extensive metabolizers suggests that PPI metabolism may play an important role in refractory GERD.

\section{PPI resistance}

A single abstract from 1995 proposed that mutations in cysteine residues of the alpha subunit of the proton pump may inhibit omeprazole binding and lead to PPI resistance, although the two patients evaluated were not found to have such mutations. ${ }^{84}$ No further studies have ever identified mutations leading to PPI resistance, suggesting that it does not play a role in refractory GERD.

\section{Other differential diagnostic considerations}

\section{Eosinophilic esophagitis}

The relationship between GERD and EoE, a chronic, immune-mediated disease characterized by symptoms of esophageal dysfunction and eosinophilic inflammation, is complex. Distinguishing EoE from GERD is challenging, as both conditions involve heartburn, chest pain, dysphagia, and esophageal eosinophilia, ${ }^{85}$ which may respond to PPIs. ${ }^{86}$ Currently, it is unclear if GERD and EOE exist independently or one may cause the other. ${ }^{85}$ Further complicating this relationship is new data suggesting that PPIs may predispose patients to developing EoE by altering mucosal immune responses and increasing exposure to food allergens (Table 2). ${ }^{86}$

The reported prevalence of EoE in patients with refractory GERD is limited and variable, with estimates ranging from $1 \%$ to $15 \% .{ }^{87-90}$ In one study of 130 patients with persistent heartburn and/or regurgitation despite receiving 6 weeks of omeprazole treatment, only one patient was found to have

Table 2 Causes unrelated to GERD

- Eosinophilic esophagitis

- Achalasia

- Zollinger-Ellison syndrome

- Pill-induced esophagitis

- Autoimmune skin diseases with esophageal manifestations

- Rumination syndrome

- Infectious esophagitis

- Esophageal cancer

- NSAID use

- Radiation-induced esophagitis

- Caustic agent ingestion

Abbreviations: GERD, gastroesophageal reflux disease; NSAID, nonsteroidal antiinflammatory drug. lesions on upper endoscopy suggestive of EoE. ${ }^{89}$ Similarly, a study of 105 patients with PPI-resistant heartburn found that only $0.9 \%$ of patients had EoE on upper endoscopy. ${ }^{90}$ Overall, EoE is a relatively uncommon disorder and unlikely to be a cause of GERD symptoms that do not respond to PPI therapy. ${ }^{91}$

\section{Helicobacter pylori status}

Studies show that PPIs are actually more effective in the setting of Helicobacter pylori infection. In patients with H. pylori, PPI treatment results in a higher intragastric $\mathrm{pH},{ }^{92}$ higher rates of healing of EE, and improvement of GERD symptoms. ${ }^{93}$ It is unclear if $H$. pylori eradication leads to worsening of GERD symptoms, as several small studies have found conflicting results. ${ }^{94}$

\section{Delayed healing}

A meta-analysis of patients with EE showed that PPIs result in healing rates and symptom response that are twice that of histamine 2 receptor antagonists (H2RAs). On PPIs, complete heartburn relief occurs at a rate of $11.5 \%$ per week. More significant disease, Los Angeles class C and D, might take longer. However, this study did not explicitly investigate the association between persistent GERD symptoms and incompletely healed EE. ${ }^{4}$ Additional data is needed to determine if delayed healing significantly contributes to resistant GERD.

\section{Barrett's esophagus (BE)}

$\mathrm{BE}$ is more prevalent in patients with GERD symptoms ${ }^{95}$ but does not appear to play a large role in PPI resistance, as the vast majority ( $80-85 \%)$ of patients with BE have full resolution of GERD symptoms with PPI therapy. ${ }^{5}$

\section{Causes unrelated to GERD}

Other diseases that are associated with heartburn should be considered in patients with refractory GERD. These include achalasia, Zollinger-Ellison syndrome, pill-induced esophagitis, autoimmune skin disease with esophageal manifestations, ${ }^{96}$ infectious esophagitis (such as candida and herpes simplex virus), ${ }^{97}$ esophageal cancer, ${ }^{98}$ nonsteroidal anti-inflammatory drug use,${ }^{99}$ rumination syndrome, ${ }^{100}$ radiation-induced esophagitis, ${ }^{101}$ and ingestion of caustic agents. ${ }^{102}$ The mechanisms of these insults make them unlikely to respond to PPI therapy.

\section{Diagnosis}

A standard evaluation of refractory GERD symptoms should include a thorough symptom evaluation, structural evaluation 
of the upper GI tract, and a functional evaluation to include assessing the nature of the refluxed material and possibly esophageal motor function (Table 3 ).

\section{Symptom evaluation}

The first step in evaluating refractory GERD is clarification of persistent symptoms and aggravating factors. Patients with refractory GERD usually report atypical burning in the upper chest or throat that is unrelated to meals and associated with belching, dyspepsia, and bloating. ${ }^{103}$ Regurgitation, or the backflow of gastric contents into the chest or mouth, ${ }^{104,105}$ is also common in refractory GERD but may be a sign of gastroparesis or rumination syndrome. ${ }^{106}$ Alarm symptoms, such as anorexia, dysphagia, odynophagia, weight loss, anemia, and GI bleeding, must also be evaluated, as they may indicate more severe disease, such as stricture formation ${ }^{107}$ or upper GI malignancy. ${ }^{108}$

\section{Upper Gl series/barium swallow}

Barium radiographs can be used to evaluate patients with esophageal symptoms, but the sensitivity of this test is extremely low. ${ }^{109}$ There is no role for barium swallow in the routine diagnosis of GERD, but it may be useful in the setting of dysphagia. ${ }^{10,111}$

\section{Upper Gl endoscopy}

The American Society of Gastrointestinal Endoscopy recommends upper GI endoscopy for patients with persistent GERD symptoms despite optimization of PPI therapy. ${ }^{112}$ When endoscopy is performed, biopsies should be obtained to rule out EoE ${ }^{22}$ and esophageal cancer. ${ }^{113}$ Endoscopy can also identify alternative causes of refractory symptoms, such as infectious esophagitis, caustic ingestion, BE, esophageal cancer, or gastric or duodenal ulcer. ${ }^{114}$

\section{Esophageal $\mathrm{pH}$ monitoring}

Esophageal $\mathrm{pH}$ monitoring is a common diagnostic tool for evaluating patients with treatment-refractory GERD. While the diagnostic yield of $\mathrm{pH}$ monitoring in patients on PPI therapy is low, it can identify refractory GERD patients

Table 3 Diagnostic tools

- Upper GI series

- Upper Gl endoscopy

- Esophageal pH monitoring

- Esophageal impedance monitoring

- Esophageal Bilitec monitoring

- Esophageal manometry

Abbreviation: $\mathrm{Gl}$, gastrointestinal. who might benefit from further PPI therapy and those whose symptoms are not related to residual acid reflux. Esophageal $\mathrm{pH}$ testing in patients with atypical symptoms who are off of treatment can determine if reflux is the cause of their initial symptoms. ${ }^{98}$

A wireless $\mathrm{pH}$ capsule is often used because it is more comfortable and can capture $\mathrm{pH}$ for several days. ${ }^{115}$ However, the value of extended $\mathrm{pH}$ monitoring remains unclear, as a recent study found that $67 \%$ of refractory GERD patients had normal $\mathrm{pH}$ testing throughout 2 days of monitoring. ${ }^{116}$ Moreover, given their inability to measure weakly acidic or alkaline reflux, both wireless and traditional $\mathrm{pH}$ monitoring have been replaced by esophageal impedance and $\mathrm{pH}$ monitoring. ${ }^{117}$

\section{Esophageal multichannel intraluminal impedance- $\mathrm{pH}$ monitoring}

In esophageal multichannel intraluminal impedance- $\mathrm{pH}$ monitoring, an intraluminal probe is placed in the esophagus with electrodes at multiple levels. Because air has a high impedance and liquid has a low impedance, both the composition and the proximal extent of a reflux event can be measured. ${ }^{114} \mathrm{~A} \mathrm{pH}$ monitor on the impedance catheter also allows the acidity of the reflux to be characterized. ${ }^{104}$ Therefore, unlike esophageal $\mathrm{pH}$ monitoring alone, intraluminal impedance monitoring can identify reflux as acidic, weakly acidic, or alkaline, and its composition as liquid, gas, or both.

\section{Esophageal Bilitec}

Bilitec utilizes a sensor mounted on a catheter to detect the presence of bilirubin in the distal esophagus as a marker for bile reflux. ${ }^{118}$ The addition of Bilitec to $\mathrm{pH}$ monitoring has been shown to clarify the composition of reflux ${ }^{70}$ and increase the rate of abnormal results by $30-40 \%$ in treatmentrefractory patients. ${ }^{119}$ It is not widely available and requires specific dietary restrictions. ${ }^{114}$

\section{Esophageal manometry}

Esophageal manometry in refractory GERD has limited benefit because most patients with treatment failure have NERD or a functional bowel disorder. ${ }^{5}$ However, esophageal manometry can be used for positioning sensors prior to $\mathrm{pH}$ monitoring and for ruling out esophageal motor disorders or achalasia. ${ }^{22}$ Manometry is also important for patients who are considering antireflux surgery, as up to $40 \%$ of patients with preoperative peristaltic dysfunction experience postoperative dysphagia. ${ }^{120}$ 


\section{Treatment}

There are a myriad of potential therapies that vary in efficacy, invasiveness, and accessibility. Most therapeutic strategies target one or more of the abovementioned underlying mechanisms (Table 4).

\section{Lifestyle modification}

Lifestyle modifications, such as elevation of the head of the bed at night, weight loss, and avoidance of alcohol, tobacco, caffeine, coffee, citrus, chocolate, and high-fat or spicy foods, are often recommended as first-line therapy for GERD despite poor evidence supporting their use. ${ }^{121} \mathrm{~A}$ meta-analysis found that GERD improved with weight loss and head elevation but not with dietary interventions or abstinence from tobacco or alcohol. ${ }^{121}$

\section{Pharmacologic treatments Double-dose PPI}

Resistant GERD is generally defined as persistent symptoms despite twice-daily PPI dosing. ${ }^{6-8}$ However, for patients who fail once-daily PPI therapy, the standard of care in clinical practice is to double the dose $\mathrm{e}^{5}$ to twice-daily dosing before breakfast and dinner.

\section{Choice of agent}

There is limited data suggesting that one PPI agent is superior to another for refractory GERD. However, if the reason for PPI failure is poor compliance, one possible solution may lie in choice of PPI. Dexlansoprazole MR, for example, employs a novel dual delayed-release formulation that allows for oncedaily dosing without regard to time of day or food consumption. ${ }^{1}$

\section{$\mathrm{PPI}+\mathrm{H} 2 \mathrm{RA}$}

H2RAs are often added to PPI therapy to control nocturnal GERD symptoms, as nocturnal acid secretion is mainly

\section{Table 4 Treatment}

- Lifestyle modification

○ Weight loss, diet

- Medications

- Antacids, motility agents, antidepressants, reflux inhibitors

- Endoscopic procedures

- TIF, MUSE, Stretta

- Surgery

○ Fundoplication

- Alternative and complementary therapies - Acupuncture, herbal treatments

Abbreviations: TIF, transoral incisionless fundoplication; MUSE, Medigus ultrasonic surgical stapler. driven by histamine and is therefore less responsive to PPI therapy. ${ }^{104}$ The addition of a nighttime H2RA to twice-daily PPI has been shown to decrease NAB from $64 \%$ to $17 \%{ }^{122}$ and improve both day- and nighttime GERD symptoms. ${ }^{123}$ However, tachyphylaxis to the acid-lowering effects of H2RAs can develop in as little as 1 week, ${ }^{124}$ suggesting their use may be of limited utility in resistant GERD.

\section{PPI + prokinetic}

Prokinetics, a group of drugs that increase esophageal and gastric motility, may be useful for patients whose refractory symptoms result from poor esophageal clearance. Prokinetics act at a variety of receptors, including 5-hydroxytryptamine (5-HT) 4, dopamine 2 (D2), motilin, and ghrelin. ${ }^{136}$ A recent meta-analysis found that the addition of a prokinetic to a PPI showed no benefit in symptom control but improved quality of life. ${ }^{126}$ Side effects, including fatigue, cardiac events, tardive dyskinesia, and tremor, have limited their use. ${ }^{127}$

\section{Metoclopramide}

Metoclopramide is a D2 receptor antagonist and 5-HT4 agonist that increases LES pressure and accelerates gastric emptying. ${ }^{128}$ Its use is often limited by significant side effects including tardive dyskinesia, agitation, and insomnia. ${ }^{129}$ The only study of metoclopramide for refractory GERD found that its use with an H2RA did not improve symptoms over the H2RA alone.$^{130}$ Additional studies are needed to assess the use of metoclopramide in conjunction with a PPI for resistant GERD.

\section{Cisapride}

Cisapride is a $5 \mathrm{HT} 4$ agonist $^{2}$ that increases lower esophageal pressure, enhances esophageal acid clearance, and promotes gastric emptying. ${ }^{131}$ In one study, cisapride in conjunction with an H2RA was found to be superior to an H2RA alone for the treatment and maintenance of heartburn symptoms. ${ }^{131}$ However, the addition of cisapride to omeprazole does not appear to improve symptom control. ${ }^{2}$ Cisapride was removed from the market in $2000^{132}$ due to severe cardiac complications including QT prolongation, arrhythmia, and death. ${ }^{133}$ Cisapride only remains available through a limited access protocol for investigational purposes or patients who have failed all other treatments. ${ }^{134}$

\section{Alginates}

Alginates, or anionic polysaccharides, such as Gaviscon, have been shown to localize to the acid pocket, ${ }^{135}$ where they precipitate into a low-density, $\mathrm{pH}$-neutral viscous gel 
that floats on top of stomach contents and impedes reflux. ${ }^{136}$ The combination of omeprazole and sodium alginate has been shown to significantly improve symptoms at 4 weeks compared to omeprazole alone. ${ }^{148}$

\section{Sucralfate}

Sucralfate is a mucosal protectant that binds to inflamed tissue and blocks the diffusion of gastric acid and pepsin across the esophageal mucosa, thereby inhibiting the erosive effects of pepsin and potentially bile. ${ }^{137}$ Sucralfate also stimulates growth factors that promote mucus and bicarbonate formation as well as ulcer healing. ${ }^{137}$ Compared with H2RAs and alginates with antacids, sucralfate is equally effective in controlling GERD symptoms associated with EE but has only been shown to heal esophageal mucosa in low-grade EE. ${ }^{138,139}$ Sucralfate is rarely used given its four times daily dosing and limited efficacy compared with PPIs but is more commonly prescribed in pregnant women, as it is not associated with maternal or fetal adverse events. ${ }^{140}$ Currently, there is no data on the role of sucralfate in patients who do not respond to PPI therapy. ${ }^{141}$

\section{Bile acid binder}

Bile acid binders, such as cholestyramine and colesevelam, should theoretically decrease bile acid reflux. However, there is no data for or against their use in PPI-resistant GERD. ${ }^{5}$

\section{Reflux inhibitors}

Distention of the proximal stomach causes a vagal-mediated relaxation of the LES, allowing reflux to occur. ${ }^{2}$ Reflux inhibitors that inhibit this relaxation are likely to be of the most benefit to patients whose symptoms are due to weakly acidic reflux or DGER. ${ }^{2}$

\section{Baclofen}

In patients with GERD, Baclofen, a GABA-B receptor agonist, has been shown to decrease transient LES relaxation by $40 \%$, increase LES pressure, and reduce the rate of reflux events. ${ }^{142}$ Most studies show that Baclofen monotherapy is effective for GERD. ${ }^{143}$ The only study that examined its use as an add-on to PPI therapy for GERD found no difference in symptoms, although this result is unsurprising given that the study was performed on patients with well-controlled GERD. ${ }^{144}$ A small study of patients with confirmed DGER and persistent symptoms despite PPI treatment found that the addition of baclofen $20 \mathrm{mg}$ three times daily leads to a significant reduction in duodenogastric reflux episodes and improvement in symptoms. ${ }^{145}$ The effect of baclofen on the central nervous system results in side effects such as dizziness, weakness, and fatigue, although these may be limited with nighttime dosing. ${ }^{146}$

\section{Antidepressants}

TCAs, selective serotonin reuptake inhibitors (SSRIs), and trazodone can potentially improve esophageal pain in patients with visceral hypersensitivity. These agents are thought to confer visceral analgesia by acting at the central nervous system and/or sensory afferents level. ${ }^{147}$ Data is strongest for the efficacy of SSRIs in acid-sensitive esophagus and functional heartburn. In a controlled trial of patients with acid-sensitive esophagus, citalopram $20 \mathrm{mg}$ daily was superior to placebo in improving regurgitation, heartburn, and chest pain. ${ }^{148}$ A study of 144 patients with refractory GERD similarly found that fluoxetine, compared with placebo and omeprazole, led to greater reductions in heartburn, and was particularly effective for patients with functional heartburn and hypersensitive esophagus. ${ }^{149}$ Controlled trials of nortriptyline do not support its use for heartburn symptoms, ${ }^{150,151}$ although observations of TCAs in healthy subjects suggest that they can decrease esophageal hypersensitivity. ${ }^{152,153}$ One hypothesis for the discrepancy between TCA and SSRI trials is that TCAs prolonged orocecal times, whereas SSRIs reduce them, potentially decreasing the window in which reflux can occur. ${ }^{154}$ Trazodone, a serotonin antagonist and reuptake inhibitor, has also been effective for relieving chest pain, dysphagia, heartburn, and regurgitation secondary to esophageal contraction abnormalities. ${ }^{44}$

\section{Procedures}

\section{Laparoscopic fundoplication}

Antireflux surgery can be considered for patients who either fail PPI therapy or have complications of reflux, such as severe esophagitis, stricture, or risk of aspiration. Surgery may also be appropriate for patients who cannot tolerate or comply with long-term pharmacotherapy. The primary surgical intervention for the treatment of GERD is laparoscopic fundoplication. Although some case series have shown that antireflux surgery improves symptoms for patients with refractory GERD, ${ }^{155,156}$ larger peer-reviewed and controlled studies suggest that surgery is primarily effective for patients who have a history of partial or complete response to PPI therapy. ${ }^{157-159}$ Outcomes from surgery are also superior for patients with typical symptoms who have objective evidence of acid reflux and good presurgical compliance with antireflux medications. ${ }^{160,161}$ Potential adverse effects of laparoscopic fundoplication include dyspepsia, 
dysphagia, and gas bloat syndrome, ${ }^{2}$ as well as recurrence of symptoms. ${ }^{162}$ Given the limitations and possible side effects of antireflux surgery, all surgical candidates should undergo a thorough assessment of symptoms and reflux monitoring off of PPI treatment. ${ }^{2}$

\section{Endoscopic procedures}

Stretta

Stretta improves refractory GERD symptoms by delivering radiofrequency energy to the LES, leading to increased basal pressure and reduced compliance. ${ }^{163}$ Stretta has been shown to improve the antireflux barrier ${ }^{164}$ as well as decrease refluxate volume, ${ }^{165}$ intraesophageal $\mathrm{pH},{ }^{166}$ and esophageal acid exposure. ${ }^{163}$ In a recent open-label trial of Stretta, 72\% of patients with refractory GERD showed normalization of GERD health-related quality-of-life (HRQL) scores, and 41\% reported complete discontinuation of PPI therapy at 10-year follow-up. ${ }^{163}$ However, data is mixed, with a recent systematic review showing no significant benefit over placebo. ${ }^{167} \mathrm{Clini}-$ cal use was previously limited by concerns for esophageal perforation, but more recent studies indicate that the most common side effect is transient chest pain that does not require treatment. ${ }^{168}$

Transoral incisionless fundoplication (TIF)

TIF is performed using the EsophyX device inserted transorally with the endoscope. EsophyX allows for creation of a fundoplication at the level of the gastroesophageal junction. ${ }^{168}$ Although limited, long-term data suggests that TIF may be effective for symptom control and decreased PPI use for 2-6 years. There is no evidence that TIF is more effective than laparoscopic Nissen fundoplication, but two recent studies demonstrated that TIF is superior to high-dose PPI therapy for controlling heartburn and regurgitation at 6-month follow-up. ${ }^{169,170}$ TIF may be most helpful for patients with hiatal hernias $<2 \mathrm{~cm}$ and Hill Grade I/II valves. ${ }^{171}$

\section{Novel procedures \\ LINX}

The LINX is a magnetic augmentation device that is surgically positioned around the LES. It was approved by the FDA in 2012 for severe, refractory GERD symptoms that do not respond to alternative treatments., ${ }^{2,172}$ Data is limited to short-term case series, ${ }^{172}$ but multiple prospective studies have demonstrated the safety and efficacy of LINX in treating patients with refractory GERD symptoms. ${ }^{173-175}$

\section{LES electrical stimulation therapy}

Another novel procedure for refractory GERD is LES electrical stimulation therapy (EST), which has been used for treating GI motility disorders. The LES stimulation system consists of an implantable pulse generator (IPG), a bipolar lead with two electrodes, and an external programmer. The IPG generates electrical stimulation to the LES 8-12 times per day for 30 minutes per session. ${ }^{176}$ Stimulation of the LES in patients with GERD has been shown to increase resting LES pressure without affecting peristalsis or LES relaxation. ${ }^{177}$ Although studies demonstrate that EST is safe and effective for refractory GERD at both 1- and 2-year follow-ups, ${ }^{178,179}$ data is restricted to short-term case series and open-label studies, and further research into the mechanism of action is needed. ${ }^{177}$

\section{Medigus ultrasonic surgical stapler (MUSE)}

The MUSE is an endoscopically inserted device that can be used to form a skin flap within the esophagus similar to TIF. ${ }^{180}$ The fundoplication is created transorally using a surgical stapler that is guided by video and ultrasound. ${ }^{181}$ A multicenter prospective trial found that at a 6-month follow-up, 73\% of patients showed a significant improvement in GERD-HRQL score, with $65 \%$ of patients completely discontinuing PPI use. ${ }^{181}$ The first 24 patients treated with MUSE suffered several adverse events including pneumomediastinum, GI hemorrhage, and empyema formation. ${ }^{181}$ However, after a redesign of the procedural protocol and the device itself, no further serious adverse events were reported. A 4-year follow-up found no new adverse events, but that the portion of patients who remained off daily PPI had decreased from $84 \%$ to $69 \%{ }^{182}$

\section{Nonpharmacologic interventions}

\section{Cognitive behavioral therapy (CBT)}

While controlled trials investigating the effects of CBT on refractory GERD are needed, data on noncardiac chest pain, ${ }^{183-185}$ as well as a large literature supporting the efficacy of CBT in reducing chronic pain, ${ }^{186}$ suggests that CBT may be helpful for managing symptoms.

\section{Hypnotherapy}

Hypnotherapy has demonstrated efficacy for IBS, ${ }^{187}$ functional dyspepsia, ${ }^{188}$ noncardiac chest pain, ${ }^{189,190}$ globus sensation, ${ }^{191}$ and heartburn. ${ }^{192}$ Studies have also shown that hypnotherapy can influence gastric acid secretion, ${ }^{193}$ gastric emptying time, ${ }^{194}$ and reflux symptoms. ${ }^{195}$ Hypnotherapy is 
thought to affect these conditions by modulating esophageal hypervigilance, a psychological process that develops through operant conditioning in patients who have unpredictable symptoms that are misattributed to certain triggers. Decreasing esophageal hypervigilance through hypnotherapy can help with behavioral avoidance, anxiety, and coping skills, which contribute to refractory symptoms. ${ }^{192}$

\section{Biofeedback}

Biofeedback employs visual and audio signals, as well as direct verbal feedback, to increase awareness of physiological functions. Although biofeedback has been effective for a variety of medical conditions, evidence supporting its use for GERD symptoms is limited. ${ }^{196}$ One prospective uncontrolled trial found that 7 of 12 patients with functional heartburn and functional chest pain refractory to acid suppression experienced symptom improvement for up to 9 months after using biofeedback to learn abdominal breathing exercises and muscle relaxation. ${ }^{197}$ Two case reports have similarly demonstrated that biofeedback can be used to teach patients how to contract and relax their abdominal muscles, leading to improvement in $\mathrm{pH}$ score and LES pressure, and decreasing number of reflux events. ${ }^{198,199}$ The use of biofeedback is limited by the need for staff training and patients who are motivated to attending multiple sessions and continue to practice techniques.

\section{Alternative and complementary treatments Acupuncture}

While the exact mechanism by which acupuncture improves GERD symptoms is unknown, proposed mechanisms include improved gastric motility and esophageal peristalsis, and decreased visceral hypersensitivity and LES relaxation. ${ }^{127}$ One randomized study of 30 patients with continued symptoms despite standard-dose PPI found that 10 sessions of acupuncture for 4 weeks experienced a significant improvement in day and nighttime heartburn as well as acid regurgitation. ${ }^{200}$

\section{Transcutaneous electrical acustimulation (TEA)}

TEA is the administration of pulses of electricity to acupoints on the arm or leg. One small, placebo-controlled study of 20 patients with refractory GERD found statistically significant improvements in LESP and symptom control for patients receiving twice-daily TEA for 4 weeks. ${ }^{201}$ TEA is also reported to reduce visceral hypersensitivity in $\mathrm{IBS}^{202}$ and improve functional dyspepsia. ${ }^{203}$

\section{Rikkunshito}

Rikkunshito is a traditional Japanese remedy that is composed of eight crushed herbs. ${ }^{204}$ It has been shown to affect nitric oxide-mediated gastric emptying, ${ }^{205}$ increase plasma ghrelin levels, ${ }^{206}$ and bind bile acids. ${ }^{207}$ Despite the widespread use of rikkunshito in Japan for a variety of GI problems, ${ }^{204}$ a recent study of healthy volunteers found no effect on gastric reflux or esophageal motility. ${ }^{208}$ However, a prospective randomized trial comparing rikkunshito with rabeprazole to double-dose rabeprazole found a similar symptom improvement in both groups and a superior improvement in a subgroup analysis of male patients. ${ }^{209}$

\section{Conclusion}

PPI-refractory GERD is a common problem affecting a large percentage of patients with GERD. Refractory GERD likely does not have a single underlying cause and may actually represent several disease states. Potential causes include medication noncompliance, visceral hypersensitivity, nonacid reflux, motility disorders, and alterations in PPI metabolism. Other disease states such as achalasia, EoE, and esophageal cancer must also be considered. The mainstay of evaluation of a patient with refractory GERD is upper GI endoscopy and impedance monitoring to clarify the nature of any residual reflux. Most therapies involve optimizing GERD treatment and targeting the underlying mechanism of resistance if identified. Therapies range from pharmacologic to procedural to alternative and complementary.

\section{Author contributions}

All authors contributed toward data analysis, drafting and revising the paper and agree to be accountable for all aspects of the work.

\section{Disclosure}

The authors report no conflicts of interest in this work.

\section{References}

1. Mermelstein J, Mermelstein AC, Chait MM. Proton pump inhibitors for the treatment of patients with erosive esophagitis and gastroesophageal reflux disease: current evidence and safety of dexlansoprazole. Clin Exp Gastroenterol. 2016;9:163-172.

2. Scarpellini E, Ang D, Pauwels A, De Santis A, Vanuytsel T, Tack J. Management of refractory typical GERD symptoms. Nat Rev Gastroenterol Hepatol. 2016;13(5):281-294.

3. Horn J. The proton-pump inhibitors: similarities and differences. Clin Ther. 2000;22(3):266-280; discussion 265.

4. Chiba N, De Gara CJ, Wilkinson JM, Hunt RH. Speed of healing and symptom relief in grade II to IV gastroesophageal reflux disease: a meta-analysis. Gastroenterology. 1997;112(6):1798-1810. 
5. Fass R, Shapiro M, Dekel R, Sewell J. Systematic review: proton-pump inhibitor failure in gastro-oesophageal reflux disease - where next? Aliment Pharmacol Ther. 2005;22(2):79-94.

6. Frazzoni M, Conigliaro R, Mirante VG, Melotti G. The added value of quantitative analysis of on-therapy impedance-pH parameters in distinguishing refractory non-erosive reflux disease from functional heartburn. Neurogastroenterol Motil. 2012;24(2):141-146, e87.

7. Kunsch S, Neesse A, Linhart T, Nell C, Gress TM, Ellenrieder V. Prospective evaluation of duodenogastroesophageal reflux in gastroesophageal reflux disease patients refractory to proton pump inhibitor therapy. Digestion. 2012;86(4):315-322.

8. Yamashita H, Ashida K, Fukuchi T, et al. Combined pH-impedance monitoring and high-resolution manometry of Japanese patients treated with proton-pump inhibitors for persistent symptoms of non-erosive reflux disease. J Smooth Muscle Res. 2012;48(5-6):125-135.

9. Van Soest EM, Siersema PD, Dieleman JP, Sturkenboom MC, Kuipers EJ. Persistence and adherence to proton pump inhibitors in daily clinical practice. Aliment Pharmacol Ther. 2006;24(2):377-385.

10. Gosselin A, Luo R, Lohoues H, et al. The impact of proton pump inhibitor compliance on health-care resource utilization and costs in patients with gastroesophageal reflux disease. Value Health. 2009;12(1):34-39.

11. Johnson DA, Lauritsen K, Junghard O, Levine D. Evaluation of symptoms is an unreliable predictor of relapse of erosive esophagitis in patients receiving maintenance PPI therapy. Gastroenterology 2003;124(4 Suppl 1):A540.

12. Fass R, Thomas S, Traxler B, Sostek M. Patient reported outcome of heartburn improvement: doubling the proton pump inhibitor (PPI) dose in patient who failed standard dose PPI vs. switching to a different PPI. Gastroenterology. 2004;146:A37.

13. Gunaratnam NT, Jessup TP, Inadomi J, Lascewski DP. Sub-optimal proton pump inhibitor dosing is prevalent in patients with poorly controlled gastro-oesophageal reflux disease. Aliment Pharmacol Ther. 2006;23(10):1473-1477.

14. Hungin AP, Rubin G, O'Flanagan H. Factors influencing compliance in long-term proton pump inhibitor therapy in general practice. $\mathrm{Br} J$ Gen Pract. 1999;49(443):463-464.

15. Chey WD, Inadomi JM, Booher AM, Sharma VK, Fendrick AM, Howden CW. Primary-care physicians' perceptions and practices on the management of GERD: results of a national survey. Am J Gastroenterol. 2005;100(6):1237-1242.

16. Klok RM, Postma MJ, van Hout BA, Brouwers JR. Meta-analysis: comparing the efficacy of proton pump inhibitors in short-term use. Aliment Pharmacol Ther. 2003;17(10):1237-1245.

17. Tack J, Drossman DA. What's new in Rome IV? Neurogastroenterol Motil. Epub 2017 Mar 17.

18. Aziz Q, Fass R, Gyawali CP, Miwa H, Pandolfino JE, Zerbib F. Functional esophageal disorders. Gastroenterology. Epub 2016 Feb 15.

19. Mainie I, Tutuian R, Shay S, et al. Acid and non-acid reflux in patients with persistent symptoms despite acid suppressive therapy: a multicentre study using combined ambulatory impedance-pH monitoring. Gut. 2006;55(10):1398-1402.

20. Sharma N, Agrawal A, Freeman J, Vela MF, Castell D. An analysis of persistent symptoms in acid-suppressed patients undergoing impedance-pH monitoring. Clin Gastroenterol Hepatol. 2008;6(5):521-524

21. Rohof WO, Bennink RJ, de Jonge H, Boeckxstaens GE. Increased proximal reflux in a hypersensitive esophagus might explain symptoms resistant to proton pump inhibitors in patients with gastroesophageal reflux disease. Clin Gastroenterol Hepatol. 2014;12(10):1647-1655.

22. Sifrim D, Zerbib F. Diagnosis and management of patients with reflux symptoms refractory to proton pump inhibitors. Gut. 2012;61(9): 1340-1354.

23. Tobey NA, Carson JL, Alkiek RA, Orlando RC. Dilated intercellular spaces: a morphological feature of acid reflux - damaged human esophageal epithelium. Gastroenterology. 1996;111(5):1200-1205.

24. Sarkar S, Thompson DG, Woolf CJ, Hobson AR, Millane T, Aziz Q. Patients with chest pain and occult gastroesophageal reflux demonstrate visceral pain hypersensitivity which may be partially responsive to acid suppression. Am J Gastroenterol. 2004;99(10):1998-2006.
25. Martinez SD, Malagon IB, Garewal HS, Cui H, Fass R. Non-erosive reflux disease (NERD) - acid reflux and symptom patterns. Aliment Pharmacol Ther. 2003;17(4):537-545.

26. Sharma A, Van Oudenhove L, Paine P, Gregory L, Aziz Q. Anxiety increases acid-induced esophageal hyperalgesia. Psychosom Med. 2010;72(8):802-809.

27. Fass R, Naliboff BD, Fass SS, et al. The effect of auditory stress on perception of intraesophageal acid in patients with gastroesophageal reflux disease. Gastroenterology. 2008;134(3):696-705.

28. Calabrese C, Bortolotti M, Fabbri A, et al. Reversibility of GERD ultrastructural alterations and relief of symptoms after omeprazole treatment. Am J Gastroenterol. 2005;100(3):537-542.

29. Edebo A, Vieth M, Tam W, et al. Circumferential and axial distribution of esophageal mucosal damage in reflux disease. Dis Esophagus. 2007;20(3):232-238.

30. Vela MF, Craft BM, Sharma N, Freeman J, Hazen-Martin D. Refractory heartburn: comparison of intercellular space diameter in documented GERD vs. functional heartburn. Am J Gastroenterol. 2011;106(5):844-850.

31. Ribolsi M, Caviglia R, Gentile M, et al. Dilated intercellular space diameters of esophageal epithelium in NERD patients with typical symptoms resistant to PPI therapy. Gastroenterolgy. 2007;132(4):A139.

32. Avidan B, Sonnenberg A, Giblovich H, Sontag SJ. Reflux symptoms are associated with psychiatric disease. Aliment Pharmacol Ther. 2001;15(12):1907-1912.

33. Hu WH, Wong WM, Lam CL, et al. Anxiety but not depression determines health care-seeking behaviour in Chinese patients with dyspepsia and irritable bowel syndrome: a population-based study. Aliment Pharmacol Ther. 2002;16(12):2081-2088.

34. Wong WM, Lai KC, Lam KF, et al. Prevalence, clinical spectrum and health care utilization of gastro-oesophageal reflux disease in a Chinese population: a population-based study. Aliment Pharmacol Ther. 2003;18(6):595-604

35. Jansson C, Nordenstedt H, Wallander MA, et al. Severe gastrooesophageal reflux symptoms in relation to anxiety, depression and coping in a population-based study. Aliment Pharmacol Ther. 2007;26(5):683-691.

36. Rubin J, Nagler R, Spiro HM, Pilot ML. Measuring the effect of emotions on esophageal motility. Psychosom Med. 1962;24:170-176.

37. Naliboff BD, Mayer M, Fass R, et al. The effect of life stress on symptoms of heartburn. Psychosom Med. 2004;66(3):426-434.

38. Helm PA, Walker SC, Pullium G. Total contact casting in diabetic patients with neuropathic foot ulcerations. Arch Phys Med Rehabil. 1984;65(11):691-693.

39. Nojkov B, Rubenstein JH, Adlis SA, et al. The influence of co-morbid IBS and psychological distress on outcomes and quality of life following PPI therapy in patients with gastro-oesophageal reflux disease. Aliment Pharmacol Ther. 2008;27(6):473-482.

40. Kim SE, Kim N, Oh S, et al. Predictive factors of response to proton pump inhibitors in Korean patients with gastroesophageal reflux disease. J Neurogastroenterol Motil. 2015;21(1):69-77.

41. Boltin D, Boaz M, Aizic S, et al. Psychological distress is not associated with treatment failure in patients with gastroesophageal reflux disease. J Psychosom Res. 2013;75(5):462-466.

42. Ruigómez A, Johansson S, Wernersson B, Fernández Cantero O, García Rodríguez LA. Gastroesophageal reflux disease in primary care: using changes in proton pump inhibitor therapy as an indicator of partial response. Scand J Gastroenterol. 2012;47(7):751-761.

43. Richter JE, Obrecht WF, Bradley LA, Young LD, Anderson KO. Psychological comparison of patients with nutcracker esophagus and irritable bowel syndrome. Dig Dis Sci. 1986;31(2):131-138.

44. Clouse RE, Lustman PJ, Eckert TC, Ferney DM, Griffith LS. Lowdose trazodone for symptomatic patients with esophageal contraction abnormalities. A double-blind, placebo-controlled trial. Gastroenterology. 1987;92(4):1027-1036.

45. Andersen LI, Jensen G. Risk factors for benign oesophageal disease in a random population sample. J Intern Med. 1991;230(1):5-10. 
46. Tutuian R; Clinical Lead Outpatient Services and Gastrointestinal Function Laboratory. Adverse effects of drugs on the esophagus. Best Pract Res Clin Gastroenterol. 2010;24(2):91-97.

47. van Soest EM, Dieleman JP, Siersema PD, Schoof L, Sturkenboom MC, Kuipers EJ. Tricyclic antidepressants and the risk of reflux esophagitis. Am J Gastroenterol. 2007;102(9):1870-1877.

48. Kamolz T, Granderath FA, Pointner R. Does major depression in patients with gastroesophageal reflux disease affect the outcome of laparoscopic antireflux surgery? Surg Endosc. 2003;17(1):55-60.

49. Biertho L, Sanjeev D, Sebajang H, Antony M, Anvari M. The influence of psychological factors on the outcomes of laparoscopic Nissen fundoplication. Ann Surg Innov Res. 2007;1:2.

50. Nastaskin I, Mehdikhani E, Conklin J, Park S, Pimentel M. Studying the overlap between IBS and GERD: a systematic review of the literature. Dig Dis Sci. 2006;51(12):2113-2120.

51. Pimentel M, Rossi F, Chow E, et al. Increased prevalence of irritable bowel syndrome in patients with gastroesophageal reflux. J Clin Gastroenterol. 2002;34(3):221-224.

52. Mönnikes H, Heading RC, Schmitt H, Doerfler H. Influence of irritable bowel syndrome on treatment outcome in gastroesophageal reflux disease. World J Gastroenterol. 2011;17(27):3235-3241.

53. Sifrim D, Castell D, Dent J, Kahrilas PJ. Gastro-oesophageal reflux monitoring: review and consensus report on detection and definitions of acid, non-acid, and gas reflux. Gut. 2004;53(7):1024-1031.

54. Takeda T, Nabae T, Kassab G, Liu J, Mittal RK. Oesophageal wall stretch: the stimulus for distension induced oesophageal sensation. Neurogastroenterol Motil. 2004;16(6):721-728.

55. de Caestecker JS, Pryde A, Heading RC. Site and mechanism of pain perception with oesophageal balloon distension and intravenous edrophonium in patients with oesophageal chest pain. Gut. 1992;33(5):580-586.

56. Siddiqui A, Rodriguez-Stanley S, Zubaidi S, Miner PB Jr. Esophageal visceral sensitivity to bile salts in patients with functional heartburn and in healthy control subjects. Dig Dis Sci. 2005;50(1):81-85.

57. Pearson JP, Parikh S, Orlando RC, et al. Review article: reflux and its consequences - the laryngeal, pulmonary and oesophageal manifestations. Conference held in conjunction with the 9th International Symposium on Human Pepsin (ISHP) Kingston-upon-Hull, UK, 21-23 April 2010. Aliment Pharmacol Ther. 2011;33(Suppl 1):1-71.

58. Emerenziani S, Ribolsi M, Guarino MP, et al. Acid reflux episodes sensitize the esophagus to perception of weakly acidic and mixed reflux in non-erosive reflux disease patients. Neurogastroenterol Motil. 2014;26(1):108-114

59. Hu WH, Martin CJ, Talley NJ. Intraesophageal acid perfusion sensitizes the esophagus to mechanical distension: a Barostat study. Am J Gastroenterol. 2000;95(9):2189-2194.

60. Mehta AJ, De Caestecker JS, Camm AJ, Northfield TC. Sensitization to painful distention and abnormal sensory perception in the esophagus. Gastroenterology. 1995;108(2):311-319.

61. Frazzoni M, Bertani H, Manta R, et al. Impairment of chemical clearance is relevant to the pathogenesis of refractory reflux oesophagitis. Dig Liver Dis. 2014;46(7):596-602.

62. Zerbib F, Roman S, Ropert A, et al. Esophageal pH-impedance monitoring and symptom analysis in GERD: a study in patients off and on therapy. Am J Gastroenterol. 2006;101(9):1956-1963.

63. Frazzoni M, Conigliaro R, Melotti G. Reflux parameters as modified by laparoscopic fundoplication in 40 patients with heartburn/regurgitation persisting despite PPI therapy: a study using impedance-pH monitoring. Dig Dis Sci. 2011;56(4):1099-1106.

64. Zerbib F, Duriez A, Roman S, Capdepont M, Mion F. Determinants of gastro-oesophageal reflux perception in patients with persistent symptoms despite proton pump inhibitors. Gut. 2008;57(2):156-160.

65. Ribolsi M, Emerenziani S, Petitti T, Addarii MC, Balestrieri P, Cicala $M$. Increased frequency and enhanced perception of reflux in nonerosive reflux disease patients non-responders to proton pump inhibitors. Dig Liver Dis. 2012;44(7):549-554.

66. Vaezi MF, Richter JE. Duodenogastroesophageal reflux and methods to monitor nonacidic reflux. Am JMed. 2001;111(Suppl 8A):160S-168S.
67. Pace F, Sangaletti O, Pallotta S, Molteni P, Porro GB. Biliary reflux and non-acid reflux are two distinct phenomena: a comparison between 24-hour multichannel intraesophageal impedance and bilirubin monitoring. Scand J Gastroenterol. 2007;42(9):1031-1039.

68. Farré R, van Malenstein H, De Vos R, et al. Short exposure of oesophageal mucosa to bile acids, both in acidic and weakly acidic conditions, can impair mucosal integrity and provoke dilated intercellular spaces. Gut. 2008;57(10):1366-1374.

69. Pardon NA, Vicario M, Vanheel H, et al. A weakly acidic solution containing deoxycholic acid induces esophageal epithelial apoptosis and impairs integrity in an in vivo perfusion rabbit model. Am JPhysiol Gastrointest Liver Physiol. 2016;310(7):G487-G496.

70. Tack J, Koek G, Demedts I, Sifrim D, Janssens J. Gastroesophageal reflux disease poorly responsive to single-dose proton pump inhibitors in patients without Barrett's esophagus: acid reflux, bile reflux, or both? Am J Gastroenterol. 2004;99(6):981-988.

71. Tavakkoli A, Sayed BA, Talley NJ, Moshiree B. Acid and non-acid reflux in patients refractory to proton pump inhibitor therapy: is gastroparesis a factor? World J Gastroenterol. 2013;19(37):6193-6198.

72. Kudara N, Chiba T, Orii S, Suzuki K. Gastric emptying of patients with persistent reflux symptoms and erosive esophagitis under PPI therapy. Neurogastroenterol Motil. 2004;16:654.

73. Mirbagheri SA, Sadeghi A, Amouie M, et al. Pyloric injection of botulinum toxin for the treatment of refractory GERD accompanied with gastroparesis: a preliminary report. Dig Dis Sci. 2008;53(10): 2621-2626.

74. Kahrilas PJ, McColl K, Fox M, et al. The acid pocket: a target for treatment in reflux disease? Am J Gastroenterol. 2013;108(7):1058-1064.

75. Jo YJ. Proton pump inhibitors reduce the size and acidity of the gastric acid pocket. J Neurogastroenterol Motil. 2015;21(1):133-134.

76. Peghini PL, Katz PO, Bracy NA, Castell DO. Nocturnal recovery of gastric acid secretion with twice-daily dosing of proton pump inhibitors. Am J Gastroenterol. 1998;93:763-767.

77. Nzeako UC, Murray JA. An evaluation of the clinical implications of acid breakthrough in patients on proton pump inhibitor therapy. Aliment Pharmacol Ther. 2002;16(7):1309-1316.

78. Orr WC, Harnish MJ. The efficacy of omeprazole twice daily with supplemental $\mathrm{H} 2$ blockade at bedtime in the suppression of nocturnal oesophageal and gastric acidity. Aliment Pharmacol Ther. 2003;17(12):1553-1558.

79. Furuta T, Shirai N, Sugimoto M, Ohashi K, Ishizaki T. Pharmacogenomics of proton pump inhibitors. Pharmacogenomics. 2004;5(2):181-202.

80. Kuo CH, Lu CY, Shih HY, et al. CYP2C19 polymorphism influences Helicobacter pylori eradication. World J Gastroenterol. 2014;20(43):16029-16036.

81. Klotz U, Schwab M, Treiber G. CYP2C19 polymorphism and proton pump inhibitors. Basic Clin Pharmacol Toxicol. 2004;95(1):2-8.

82. Ichikawa H, Sugimoto M, Sugimoto K, Andoh A, Furuta T. Rapid metabolizer genotype of CYP2C19 is a risk factor of being refractory to proton pump inhibitor therapy for reflux esophagitis. J Gastroenterol Hepatol. 2016;31(4):716-726.

83. Chen WY, Chang WL, Tsai YC, Cheng HC, Lu CC, Sheu BS. Doubledosed pantoprazole accelerates the sustained symptomatic response in overweight and obese patients with reflux esophagitis in Los Angeles grades A and B. Am J Gastroenterol. 2010;105(5):1046-1052.

84. Leite L, Lambrecht N, Sachs G, Castell D, Lagerström P. Is omeprazole resistance due to mutations of cysteine 813 or 822 in the acid pump? Gastroenterology. 1995;108(4):A147.

85. Kia L, Hirano I. Distinguishing GERD from eosinophilic oesophagitis: concepts and controversies. Nat Rev Gastroenterol Hepatol. 2015;12(7):379-386.

86. Cheng E, Souza RF, Spechler SJ. Eosinophilic esophagitis: interactions with gastroesophageal reflux disease. Gastroenterol Clin North Am. 2014;43(2):243-256.

87. Markowitz JE, Liacouras CA. Eosinophilic esophagitis. Gastroenterol Clin North Am. 2003;32(3):949-966. 
88. Foroutan M, Norouzi A, Molaei M, et al. Eosinophilic esophagitis in patients with refractory gastroesophageal reflux disease. Dig Dis Sci. 2010;55(1):28-31.

89. Sá CC, Kishi HS, Silva-Werneck AL, et al. Eosinophilic esophagitis in patients with typical gastroesophageal reflux disease symptoms refractory to proton pump inhibitor. Clinics (Sao Paulo). 2011;66(4):557-561.

90. Poh CH, Gasiorowska A, Navarro-Rodriguez T, et al. Upper GI tract findings in patients with heartburn in whom proton pump inhibitor treatment failed versus those not receiving antireflux treatment. Gastrointest Endosc. 2010;71(1):28-34.

91. Fass R. Proton-pump inhibitor therapy in patients with gastrooesophageal reflux disease: putative mechanisms of failure. Drugs. 2007;67(11):1521-1530.

92. Verdú EF, Armstrong D, Fraser R, et al. Effect of Helicobacter pylori status on intragastric $\mathrm{pH}$ during treatment with omeprazole. Gut. 1995;36(4):539-543.

93. Holtmann G, Cain C, Malfertheiner P. Gastric Helicobacter pylori infection accelerates healing of reflux esophagitis during treatment with the proton pump inhibitor pantoprazole. Gastroenterology. 1999;117(1):11-16.

94. Richter JE. Effect of Helicobacter pylori eradication on the treatment of gastro-oesophageal reflux disease. Gut. 2004;53(2):310-311.

95. Fass R, Sampliner RE. Barrett's oesophagus: optimal strategies for prevention and treatment. Drugs. 2003;63(6):555-564.

96. Fass R, Gasiorowska A. Refractory GERD: what is it? Curr Gastroenterol Rep. 2008;10(3):252-257.

97. Liu JJ, Saltzman JR. Refractory gastro-oesophageal reflux disease: diagnosis and management. Drugs. 2009;69(14):1935-1944.

98. Subramanian CR, Triadafilopoulos G. Refractory gastroesophageal reflux disease. Gastroenterol Rep. 2015;3(1):41-53.

99. Moraes-Filho JP. Refractory gastroesophageal reflux disease. Arq Gastroenterol. 2012;49(4):296-301.

100. Kahrilas PJ, Keefer L, Pandolfino JE. Patients with refractory reflux symptoms: what do they have and how should they be managed? Neurogastroenterol Motil. 2015;27(9):1195-1201.

101. Shields H, Li J, Pelletier S, et al. Persistence of dysphagia and odynophagia after mediastinal radiation and chemotherapy in patients with lung cancer or lymphoma. Dis Esophagus. 2017;30(2):1-8.

102. Kahrilas PJ, Shaheen NJ, Vaezi MF, et al. American Gastroenterological Association Medical Position Statement on the management of gastroesophageal reflux disease. Gastroenterology. 2008;135(4):1383-1391, 1391.e1-e5.

103. Oh TH. Accuracy of the diagnosis of GORD by questionnaire, physicians and a trial of proton pump inhibitor treatment: the Diamond Study (Gut 2010;59:714-721). J Neurogastroenterol Motil. 2011;17(1):98-99.

104. Kahrilas PJ, Boeckxstaens G, Smout AJ. Management of the patient with incomplete response to PPI therapy. Best Pract Res Clin Gastroenterol. 2013;27(3):401-414.

105. Kahrilas PJ, Howden CW, Hughes N. Response of regurgitation to proton pump inhibitor therapy in clinical trials of gastroesophagea reflux disease. Am J Gastroenterol. 2011;106(8):1419-1425; quiz 1426.

106. Tack J, Blondeau K, Boecxstaens V, Rommel N. Review article: the pathophysiology, differential diagnosis and management of rumination syndrome. Aliment Pharmacol Ther. 2011;33(7):782-788.

107. DeVault KR, Castell DO; American College of Gastroenterology. Updated guidelines for the diagnosis and treatment of gastroesophageal reflux disease. Am J Gastroenterol. 2005;100(1):190-200.

108. Talley NJ; American Gastroenterological Association. American Gastroenterological Association medical position statement: evaluation of dyspepsia. Gastroenterology. 2005;129(5):1753-1755.

109. Johnston BT, Troshinsky MB, Castell JA, Castell DO. Comparison of barium radiology with esophageal $\mathrm{pH}$ monitoring in the diagnosis of gastroesophageal reflux disease. Am J Gastroenterol. 1996;91(6):1181-1185.

110. Richter JE, Castell DO. Gastroesophageal reflux. Pathogenesis, diagnosis, and therapy. Ann Intern Med. 1982;97(1):93-103.

111. Keung $\mathrm{C}$, Hebbard G. The management of gastro-oesophageal reflux disease. Aust Prescr. 2016;39(1):6-10.
112. Katz PO, Gerson LB, Vela MF. Guidelines for the diagnosis and management of gastroesophageal reflux disease. Am J Gastroenterol. 2013;108(3):308-328; quiz 329.

113. Richter JE. How to manage refractory GERD. Nat Clin Pract Gastroenterol Hepatol. 2007;4(12):658-664.

114. Fass R, Sifrim D. Management of heartburn not responding to proton pump inhibitors. Gut. 2009;58(2):295-309.

115. Prakash C, Clouse RE. Value of extended recording time with wireless $\mathrm{pH}$ monitoring in evaluating gastroesophageal reflux disease. Clin Gastroenterol Hepatol. 2005;3(4):329-334.

116. Turner BG, Saltzman JR, Hua L, et al. Endoscopic pH monitoring for patients with suspected or refractory gastroesophageal reflux disease. Can J Gastroenterol. 2007;21(11):737-741.

117. Hirano I, Zhang Q, Pandolfino JE, Kahrilas PJ. Four-day Bravo pH capsule monitoring with and without proton pump inhibitor therapy. Clin Gastroenterol Hepatol. 2005;3(11):1083-1088.

118. Pohl D, Tutuian R. Reflux monitoring: pH-metry, Bilitec and oesophageal impedance measurements. Best Pract Res Clin Gastroenterol. 2009;23(3):299-311.

119. Karamanolis G, Vanuytsel T, Sifrim D, et al. Yield of 24-hour esophageal $\mathrm{pH}$ and bilitec monitoring in patients with persisting symptoms on PPI therapy. Dig Dis Sci. 2008;53(9):2387-2393.

120. Pandolfino JE, Kahrilas PJ; American Gastroenterological Association. AGA technical review on the clinical use of esophageal manometry. Gastroenterology. 2005;128(1):209-224.

121. Kaltenbach T, Crockett S, Gerson LB. Are lifestyle measures effective in patients with gastroesophageal reflux disease? An evidence-based approach. Arch Intern Med. 2006;166(9):965-971.

122. Mainie I, Tutuian R, Castell DO. Addition of a $\mathrm{H} 2$ receptor antagonist to PPI improves acid control and decreases nocturnal acid breakthrough. J Clin Gastroenterol. 2008;42(6):676-679.

123. Rackoff A, Agrawal A, Hila A, Mainie I, Tutuian R, Castell DO. Histamine-2 receptor antagonists at night improve gastroesophageal reflux disease symptoms for patients on proton pump inhibitor therapy. Dis Esophagus. 2005;18(6):370-373.

124. Fackler WK, Ours TM, Vaezi MF, Richter JE. Long-term effect of H2RA therapy on nocturnal gastric acid breakthrough. Gastroenterology. 2002;122(3):625-632.

125. Wang YK, Hsu WH, Wang S, et al. Current pharmacological management of gastroesophageal reflux disease. Gastroenterol Res Pract. 2013;2013:983653.

126. Ren, LH, Chen WX, Qian LJ, Li S, Gu M, Shi RH. Addition of prokinetics to PPI therapy in gastroesophageal reflux disease: a metaanalysis. World J Gastroenterol. 2014;20(9):2412-2419.

127. Patrick L. Gastroesophageal reflux disease (GERD): a review of conventional and alternative treatments. Altern Med Rev. 2011;16(2):116-133.

128. Acosta A, Camilleri M. Prokinetics in gastroparesis. Gastroenterol Clin North Am. 2015;44(1):97-111.

129. Chait MM. Gastroesophageal reflux disease: important considerations for the older patients. World $J$ Gastrointest Endosc. 2010;2(12):388-396.

130. Richter JE, Sabesin SM, Kogut DG, Kerr RM, Wruble LD, Collen MJ. Omeprazole versus ranitidine or ranitidine/metoclopramide in poorly responsive symptomatic gastroesophageal reflux disease. Am J Gastroenterol. 1996;91(9):1766-1772.

131. Galmiche JP, Brandstätter G, Evreux M, et al. Combined therapy with cisapride and cimetidine in severe reflux oesophagitis: a double blind controlled trial. Gut. 1988;29(5):675-681.

132. Qureshi ZP, Seoane-Vazquez E, Rodriguez-Monguio R, Stevenson KB, Szeinbach SL. Market withdrawal of new molecular entities approved in the United States from 1980 to 2009. Pharmacoepidemiol Drug Saf. 2011;20(7):772-777.

133. Tack J, Camilleri M, Chang L, et al. Systematic review: cardiovascular safety profile of 5-HT(4) agonists developed for gastrointestinal disorders. Aliment Pharmacol Ther. 2012;35(7):745-767.

134. Michalets EL, Williams CR. Drug interactions with cisapride: clinical implications. Clin Pharmacokinet. 2000;39(1):49-75. 
135. Rohof WO, Bennink RJ, Smout AJ, Thomas E, Boeckxstaens GE. An alginate-antacid formulation localizes to the acid pocket to reduce acid reflux in patients with gastroesophageal reflux disease. Clin Gastroenterol Hepatol. 2013;11(12):1585-1591; quiz e90.

136. Manabe N, Haruma K, Ito M, et al. Efficacy of adding sodium alginate to omeprazole in patients with nonerosive reflux disease: a randomized clinical trial. Dis Esophagus. 2012;25(5):373-380.

137. Hershcovici T, Fass R. Pharmacological management of GERD: where does it stand now? Trends Pharmacol Sci. 2011;32(4):258-264.

138. Simon B, Mueller P. Comparison of the effect of sucralfate and ranitidine in reflux esophagitis. Am J Med. 1987;83(3B):43-47.

139. Hameeteman W, v d Boomgaard DM, Dekker W, Schrijver M, Wesdorp IC, Tytgat GN. Sucralfate versus cimetidine in reflux esophagitis. A single-blind multicenter study. J Clin Gastroenterol. 1987;9(4): 390-394.

140. Richter JE. Review article: the management of heartburn in pregnancy. Aliment Pharmacol Ther. 2005;22(9):749-757.

141. Hussain ZH, Henderson EE, Maradey-Romerao C, George N, Fass $\mathrm{R}$, Lacy BE. The proton pump inhibitor non-responder: a clinical conundrum. Clin Transl Gastroenterol. 2015;6:e106.

142. Zhang Q, Lehmann A, Rigda R, Dent J, Holloway RH. Control of transient lower oesophageal sphincter relaxations and reflux by the $\mathrm{GABA}(\mathrm{B})$ agonist baclofen in patients with gastro-oesophageal reflux disease. Gut. 2002;50(1):19-24.

143. Li S, Shi S, Chen F, Lin J. The effects of baclofen for the treatment of gastroesophageal reflux disease: a meta-analysis of randomized controlled trials. Gastroenterol Res Pract. 2014;2014:307805.

144. Beaumont H, Boeckxstaens GE. Does the presence of a hiatal hernia affect the efficacy of the reflux inhibitor baclofen during add-on therapy? Am J Gastroenterol. 2009;104(7):1764-1771.

145. Koek GH, Sifrim D, Lerut T, Janssens J, Tack J. Effect of the GABA(B) agonist baclofen in patients with symptoms and duodenogastro-oesophageal reflux refractory to proton pump inhibitors. Gut. 2003;52(10):1397-1402.

146. Orr WC, Goodrich S, Wright S, Shepherd K, Mellow M. The effect of baclofen on nocturnal gastroesophageal reflux and measures of sleep quality: a randomized, cross-over trial. Neurogastroenterol Motil. 2012;24(6):553-559, e253.

147. Bradesi S, Herman J, Mayer EA. Visceral analgesics: drugs with a great potential in functional disorders? Curr Opin Pharmacol. 2008;8(6):697-703.

148. Viazis N, Keyoglou A, Kanellopoulos AK, et al. Selective serotonin reuptake inhibitors for the treatment of hypersensitive esophagus: a randomized, double-blind, placebo-controlled study. Am J Gastroenterol. 2012;107(11):1662-1667.

149. Ostovaneh MR, Saeidi B, Hajifathalian K, et al. Comparing omeprazole with fluoxetine for treatment of patients with heartburn and normal endoscopy who failed once daily proton pump inhibitors: double-blind placebo-controlled trial. Neurogastroenterol Motil. 2014;26(5):670-678.

150. Hershcovici T, Jha LK, Gadam R, et al. Comparison of therapeutic strategies for patients with refractory gastroesophageal reflux disease (GERD) - a randomized, double blind, placebo-controlled trial. Gastroenterology. 2011;140(5 Suppl 1):S579.

151. Forcelini CM, Tomiozzo JC Jr, Farré R, et al. Effect of nortriptyline on brain responses to painful esophageal acid infusion in patients with non-erosive reflux disease. Neurogastroenterol Motil. 2014;26(2):187-195.

152. Gorelick AB, Koshy SS, Hooper FG, Bennett TC, Chey WD, Hasler WL. Differential effects of amitriptyline on perception of somatic and visceral stimulation in healthy humans. Am J Physiol. 1998;275(3 Pt 1): G460-G466

153. Peghini PL, Katz PO, Castell DO. Imipramine decreases oesophageal pain perception in human male volunteers. Gut. 1998;42(6): 807-813.
154. Rohof WO, Bennink RJ, de Ruigh AA, Hirsch DP, Zwinderman AH, Boeckxstaens GE. Effect of azithromycin on acid reflux, hiatus hernia and proximal acid pocket in the postprandial period. Gut. 2012;61(12):1670-1677.

155. Wilkerson PM, Stratford J, Jones L, Sohanpal J, Booth MI, Dehn TC. A poor response to proton pump inhibition is not a contraindication for laparoscopic antireflux surgery for gastro esophageal reflux disease. Surg Endosc. 2005;19(9):1272-1277.

156. Hamdy E, El Nakeeb A, Hamed H, El Hemaly M, ElHak NG. Outcome of laparoscopic Nissen fundoplication for gastroesophageal reflux disease in non-responders to proton pump inhibitors. $J$ Gastrointest Surg. 2014;18(9):1557-1562.

157. Anvari M, Allen C. Five-year comprehensive outcomes evaluation in 181 patients after laparoscopic Nissen fundoplication. J Am Coll Surg. 2003;196(1):51-57; discussion 57-58; author reply 58-59.

158. Gillies RS, Stratford JM, Booth MI, Dehn TC. Does laparoscopic antireflux surgery improve quality of life in patients whose gastrooesophageal reflux disease is well controlled with medical therapy? Eur J Gastroenterol Hepatol. 2008;20(5):430-435.

159. Hatlebakk JG, Zerbib F, Bruley des Varannes S, et al; LOTUS Study Group. Gastroesophageal acid reflux control 5 years after antireflux surgery, compared with long-term esomeprazole therapy. Clin Gastroenterol Hepatol. 2016;14(5):678-685.e3.

160. Hayden JD, Jamieson GG. Optimization of outcome after laparoscopic antireflux surgery. ANZ J Surg. 2006;76(4):258-263.

161. Csendes A. Multivariate analysis of factors predicting outcome after laparoscopic Nissen fundoplication. J Gastrointest Surg. 2000;4(6):650.

162. Lundell L, Bell M, Ruth M. Systematic review: laparoscopic fundoplication for gastroesophageal reflux disease in partial responders to proton pump inhibitors. World J Gastroenterol. 2014;20(3):804-813.

163. Noar M, Squires P, Noar E, Lee M. Long-term maintenance effect of radiofrequency energy delivery for refractory GERD: a decade later. Surg Endosc. 2014;28(8):2323-2333.

164. Corley DA, Katz P, Wo JM, et al. Improvement of gastroesophageal reflux symptoms after radiofrequency energy: a randomized, shamcontrolled trial. Gastroenterology. 2003;125(3):668-676.

165. Arts J, Bisschops R, Blondeau K, et al. A double-blind sham-controlled study of the effect of radiofrequency energy on symptoms and distensibility of the gastro-esophageal junction in GERD. Am J Gastroenterol. 2012;107(2):222-230.

166. Triadafilopoulos G. Changes in GERD symptom scores correlate with improvement in esophageal acid exposure after the Stretta procedure. Surg Endosc. 2004;18(7):1038-1044.

167. Lipka S, Kumar A, Richter JE. No evidence for efficacy of radiofrequency ablation for treatment of gastroesophageal reflux disease: a systematic review and meta-analysis. Clin Gastroenterol Hepatol. 2015;13(6):1058-1067.e1.

168. Hopkins J, Switzer NJ, Karmali S. Update on novel endoscopic therapies to treat gastroesophageal reflux disease: a review. World $J$ Gastrointest Endosc. 2015;7(11):1039-1044.

169. Trad KS, Barnes WE, Simoni G, et al. Transoral incisionless fundoplication effective in eliminating GERD symptoms in partial responders to proton pump inhibitor therapy at 6 months: the TEMPO Randomized Clinical Trial. Surg Innov. 2015;22(1):26-40.

170. Hunter JG, Kahrilas PJ, Bell RC, et al. Efficacy of transoral fundoplication vs omeprazole for treatment of regurgitation in a randomized controlled trial. Gastroenterology. 2015;148:324-333.e5.

171. Bell RC, Mavrelis PG, Barnes WE, et al. A prospective multicenter registry of patients with chronic gastroesophageal reflux disease receiving transoral incisionless fundoplication. J Am Coll Surg. 2012;215(6):794-809.

172. Skubleny D, Switzer NJ, Dang J, et al. LINX(®) magnetic esophageal sphincter augmentation versus Nissen fundoplication for gastroesophageal reflux disease: a systematic review and meta-analysis. Surg Endosc. 2017;31(8):3078-3084. 
173. Bonavina L, Saino G, Bona D, Sironi A, Lazzari V. One hundred consecutive patients treated with magnetic sphincter augmentation for gastroesophageal reflux disease: 6 years of clinical experience from a single center. J Am Coll Surg. 2013;217(4):577-585.

174. Lipham JC, Taiganides PA, Louie BE, Ganz RA, DeMeester TR. Safety analysis of first 1000 patients treated with magnetic sphincter augmentation for gastroesophageal reflux disease. Dis Esophagus. 2015;28(4):305-311.

175. Saino G, Bonavina L, Lipham JC, Dunn D, Ganz RA. Magnetic sphincter augmentation for gastroesophageal reflux at 5 years: final results of a pilot study show long-term acid reduction and symptom improvement. J Laparoendosc Adv Surg Tech A . 2015;25(10):787-792.

176. Rinsma NF, Bouvy ND, Masclee AA, Conchillo JM. Electrical stimulation therapy for gastroesophageal reflux disease. J Neurogastroenterol Motil. 2014;20(3):287-293.

177. Rodríguez L, Rodríguez P, Neto MG, et al. Short-term electrical stimulation of the lower esophageal sphincter increases sphincter pressure in patients with gastroesophageal reflux disease. Neurogastroenterol Motil. 2012;24(5):446-450, e213.

178. Rodríguez L, Rodriguez P, Gómez B, et al. Long-term results of electrical stimulation of the lower esophageal sphincter for the treatment of gastroesophageal reflux disease. Endoscopy. 2013;45(8):595-604

179. Rodríguez L, Rodriguez P, Gómez B, et al. Two-year results of intermittent electrical stimulation of the lower esophageal sphincter treatment of gastroesophageal reflux disease. Surgery. 2015;157(3):556-567.

180. Nabi Z, Reddy DN. Endoscopic management of gastroesophageal reflux disease: revisited. Clin Endosc. 2016;49(5):408-416.

181. Zacherl J, Roy-Shapira A, Bonavina L, et al. Endoscopic anterior fundoplication with the Medigus Ultrasonic Surgical Endostapler (MUSETM) for gastroesophageal reflux disease: 6-month results from a multi-center prospective trial. Surg Endosc. 2015;29(1):220-229.

182. Kim HJ, Kwon CI, Kessler WR, et al. Long-term follow-up results of endoscopic treatment of gastroesophageal reflux disease with the MUSETM endoscopic stapling device. Surg Endosc. 2016;30(8):3402-3408.

183. Dickman R, Fass R. Functional heartburn. Curr Treat Options Gastroenterol. 2005;8(4):285-291.

184. Klimes I, Mayou RA, Pearce MJ, Coles L, Fagg JR. Psychological treatment for atypical non-cardiac chest pain: a controlled evaluation. Psychol Med. 1990;20(3):605.

185. van Peski-Oosterbaan AS, Spinhoven P, van Rood Y, van der Does JW, Bruschke AV, Rooijmans HG. Cognitive-behavioral therapy for noncardiac chest pain: a randomized trial. Am J Med 1999;106(4):424-429.

186. Morley S, Eccleston C, Williams A. Systematic review and metaanalysis of randomized controlled trials of cognitive behaviour therapy and behaviour therapy for chronic pain in adults, excluding headache. Pain. 1999;80(1-2):1-13.

187. Ford AC, Quigley EM, Lacy BE, et al. Effect of antidepressants and psychological therapies, including hypnotherapy, in irritable bowel syndrome: systematic review and meta-analysis. Am J Gastroenterol. 2014;109(9):1350-1365; quiz 1366.

188. Calvert EL, Houghton LA, Cooper P, Morris J, Whorwell PJ. Long-term improvement in functional dyspepsia using hypnotherapy. Gastroenterology. 2002;123(6):1778-1785.

189. Jones H, Cooper P, Miller V, Brooks N, Whorwell PJ. Treatment of non-cardiac chest pain: a controlled trial of hypnotherapy. Gut. 2006;55(10):1403-1408.

190. Miller V, Jones H, Whorwell PJ. Hypnotherapy for non-cardiac chest pain: long-term follow-up. Gut. 2007;56(11):1643.

191. Kiebles JL, Kwiatek MA, Pandolfino JE, Kahrilas PJ, Keefer L. Do patients with globus sensation respond to hypnotically assisted relaxation therapy? A case series report. Dis Esophagus. 2010;23(7):545-553.
192. Riehl ME, Pandolfino JE, Palsson OS, Keefer L. Feasibility and acceptability of esophageal-directed hypnotherapy for functional heartburn. Dis Esophagus. 2016;29(5):490-496.

193. Button LL, Russell DG, Klein HL, Medina-Acosta E, Karess RE, McMaster WR. Genes encoding the major surface glycoprotein in Leishmania are tandemly linked at a single chromosomal locus and are constitutively transcribed. Mol Biochem Parasitol. 1989;32(2-3):271-283.

194. Chiarioni G, Vantini I, De Iorio F, Benini L. Prokinetic effect of gut-oriented hypnosis on gastric emptying. Aliment Pharmacol Ther. 2006;23(8):1241-1249.

195. Scarinci IC, McDonald-Haile J, Bradley LA, Richter JE. Altered pain perception and psychosocial features among women with gastrointestinal disorders and history of abuse: a preliminary model. Am J Med. 1994;97(2):108-118.

196. Locke GR 3rd, Horwhat J, Mashimo H, et al. Endotherapy for and tailored approaches to treating GERD, and refractory GERD. Ann $N$ Y Acad Sci. 2013;1300:166-186.

197. Shapiro M, Shanani R, Taback H, Abramowich D, Scapa E, Broide E. Functional chest pain responds to biofeedback treatment but functional heartburn does not: what is the difference? Eur J Gastroenterol Hepatol. 2012;24(6):708-714.

198. Gordon A, Gordon E, Berelowitz M, Bremner CH, Bremner CG. Biofeedback improvement of lower esophageal sphincter pressures and reflux symptoms. J Clin Gastroenterol. 1983;5(3):235-237.

199. Shay SS, Johnson LF, Wong RK, et al. Rumination, heartburn, and daytime gastroesophageal reflux. A case study with mechanisms defined and successfully treated with biofeedback therapy. $J$ Clin Gastroenterol. 1986;8(2):115-126.

200. Dickman R, Schiff E, Holland A, et al. Clinical trial: acupuncture vs. doubling the proton pump inhibitor dose in refractory heartburn. Aliment Pharmacol Ther. 2007;26(10):1333-1344.

201. Meng LN, Chen S, Chen JD, Jin HF, Lu B. Effects of transcutaneous electrical acustimulation on refractory gastroesophageal reflux disease. Evid Based Complement Alternat Med. 2016;2016:8246171.

202. Xing J, Larive B, Mekhail N, Soffer E. Transcutaneous electrical acustimulation can reduce visceral perception in patients with the irritable bowel syndrome: a pilot study. Altern Ther Health Med. 2004;10(1):38-42.

203. Köklü S, Köklü G, Ozgüçlü E, Kayani GU, Akbal E, Hasçelik Z. Clinical trial: interferential electric stimulation in functional dyspepsia patients - a prospective randomized study. Aliment Pharmacol Ther. 2010;31(9):961-968.

204. Suzuki H, Inadomi JM, Hibi T. Japanese herbal medicine in functional gastrointestinal disorders. Neurogastroenterol Motil. 2009;21(7):688-696.

205. Kido T, Nakai Y, Kase Y, et al. Effects of rikkunshi-to, a traditional Japanese medicine, on the delay of gastric emptying induced by $\mathrm{N}(\mathrm{G})$ nitro-L-arginine. J Pharmacol Sci. 2005;98(2):161-167.

206. Takeda H, Sadakane C, Hattori T, et al. Rikkunshito, an herbal medicine, suppresses cisplatin-induced anorexia in rats via 5-HT2 receptor antagonism. Gastroenterology. 2008;134(7):2004-2013.

207. Araki Y, Mukaisho KI, Fujiyama Y, Hattori T, Sugihara H. The herbal medicine rikkunshito exhibits strong and differential adsorption properties for bile salts. Exp Ther Med. 2012;3(4):645-649.

208. Morita T, Furuta K, Adachi K, et al. Effects of rikkunshito (TJ-43) on esophageal motor function and gastroesophageal reflux. J Neurogastroenterol Motil. 2012;18(2):181-186.

209. Tominaga K, Iwakiri R, Fujimoto K, et al. Rikkunshito improves symptoms in PPI-refractory GERD patients: a prospective, randomized, multicenter trial in Japan. J Gastroenterol. 2012;47(3):284-292. 


\section{Publish your work in this journal}

Clinical and Experimental Gastroenterology is an international, peerreviewed, open access, online journal publishing original research, reports, editorials, reviews and commentaries on all aspects of gastroenterology in the clinic and laboratory. This journal is included on PubMed. The manuscript management system is completely online and includes a very quick and fair peer-review system, which is all easy to use. Visit http://www.dovepress.com/testimonials.php to read real quotes from published authors.

Submit your manuscript here: https://www.dovepress.com/clinical-and-experimental-gastroenterology-journal 